\title{
Contact Based School Intervention Program: Enhancing Coopera- tion Intention and Reducing Prejudice toward Roma
}

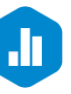

Juraj Petrík (D) , Miroslav Popper (i)

Institute of Applied Psychology, Faculty of Social and Economic Sciences, Comenius University, Mlynské Luhy 4, 82105 Bratislava, Slovak Republic

\begin{abstract}
The aim of the paper is to assess the effects of an intervention program derived from the contact theory of intergroup attitudes toward the Roma minority. A sample of 150 high school students from two midsized towns were randomly assigned to a control group and an experimental group. Participants in the experimental group attended six sessions of a Junior Project Manager program run by a local organization, which included project management lessons, a lesson on the discriminated minority and positive, cooperative direct contact with the Roma minority in work settings. Participant attitudes were measured prior to and after the intervention program. The intervention program had a positive impact on intergroup attitudes, intergroup trust, approach/avoid tendencies and intended future cooperation. The results indicate that this was the first successful attempt to change intergroup attitudes using direct contact in a Slovak context.
\end{abstract}

Key words: adolescents, intervention program, prejudice reduction, Roma minority

\section{Introduction}

The study of intergroup attitudes and relations has a long history in social psychology (Pettigrew \& Tropp, 2006). Stereotypes, "cognitive structures that contain the perceiver's knowledge, beliefs, and expectancies about some human group" (Hamilton \& Trolier, 1986, p. 133), are often accompanied by prejudice. There is a growing need to study ethnic based prejudice and develop tools to reduce it. Reasons range from societal ones, such as the recent escalation in support for extreme right-wing parties in Europe (Minkenberg, 2017), to individual ones, like the clear connection between discrimination and deterioration in psychological and mental health (Pascoe \& Richman, 2009). Additionally, people living in communities with higher levels of racial prejudice are at an elevated risk of mortality (Lee, Muennig, Kawachi, \& Hatzenbuehler, 2015). The last Eurobarometer survey on discrimination (European Commission, 2015)

Correspondence concerning this article should be addressed to Juraj Petrík, Institute of Applied Psychology, Faculty of Social and Economic Sciences, Comenius University, Mlynské Luhy 4, 82105 Bratislava, Slovak Republic. E-mail: petrik38@uniba.sk

Supplementary information for this article can be accessed at https://journals.savba.sk/index.php/studiapsychologica/article/view/85 
showed that ethnic prejudice was increasing across countries, particularly in relation to the Roma ( $+8 \%$ on the previous survey in 2012). In Slovakia a survey of 1,084 adolescent showed $28 \%$ of them would prefer to maintain their distance from the Roma, $14 \%$ of them would prefer there are no Roma people in Slovakia and $43 \%$ of those between 17 and 20 years old would vote for the Slovak radical rightwing party, L'SNS (Tomková, 2016). Analyses of free associations about the Roma population among a mixed sample of Slovak high school and university students revealed that the following categories were most saturated: 1) living conditions-disgusts, 2) dependent on state support, 3) categorization-stereotypes and 4) negative attributes-behavior (Lášticová \& Andraščiková, 2016).

It is important to emphasize that the Slovak cultural context is highly prejudicial, which presents challenges when conducting attitudinal interventions (Lášticová \& Findor, 2016). The main purpose of our study was to change intergroup attitudes through direct contact. There has been little research investigating the effectiveness of contact prejudice reduction strategies in a highly prejudicial social environment (e.g., Kende, Tropp, \& Lantos, 2017). Our aim is to contribute to the scholarly literature in this domain by creating a more optimal experimental design. Recent skepticism regarding direct contact (Paluck, Green, \& Green, 2018) has highlighted the lack of experimental field studies using randomization.

\section{Prejudice Against the Roma and the Labor Market}

The Slovak Roma population can be divided into three groups of approximately the same size: fully integrated Roma, partially integrated Roma and segregated Roma (Popper, Szeghy, \& Sarkózy, 2009). The segregated group consists of Slovak Roma faced with great social and economic difficulties, and high unemployment rates (Lajčáková, Gallová-Kriglerová, Kadlečíková, Balážová, \& Chudžíková, 2017; Mušinka, Škobla, Hurrle, Matlovičová, \& Kling, 2014). Vašečka (2011) points out that although the Slovak Roma are ethnically, socially and culturally diverse, the majority of the Slovak population perceives them negatively, as a single group living on the edge of society. The consequences can be observed in the Roma minority's ability to access the Slovak labor market (Marcinčin \& Marcinčinová, 2014). Previous research on minority societal inclusion has identified labor market integration as a key area (Mušinka \& Pollák, 2014). We argue that organizations and workplaces need to be tested to see whether they are suitable for direct intergroup contact as, besides reducing prejudice, it could increase intergroup cooperation intention.

\section{Interventions for Reducing Prejudice}

Adolescents are an important target group for attitude focused interventions, as their cognitive traits are still being formed and prejudice can affect cognition and behavior in a wide variety of domains (Bigler \& Liben, 2006). There is a wide range of interventions and theoretical approaches for reducing intergroup prejudice among adolescents (see e.g., Oskamp, 2000; Paluck \& Green, 2009). The most prominent theoretical concept is the intergroup contact hypothesis. Allport's intergroup contact hypothesis posits that intergroup prejudice decreases following intergroup contact under conditions of equal status, common goals and intergroup cooperation, third party support and an absence of competition (Allport, 1954; Pettigrew \& Tropp, 2006). Drál' and Findor (2016) have noted unrepresentative results showing that greater acceptance of Roma is generally associated with higher levels of direct experience. So far there is no 
empirical evidence of the effect of direct contact in a Slovak context.

Improving knowledge of the outgroup is one of the factors mediating prejudice reduction within groups (Pettigrew \& Tropp, 2008) and that leads to more positive intergroup relations (Beelmann \& Heinemann, 2014). Although direct contact and information acquisition have proved effective in reducing prejudice in single intervention studies (e.g., Orosz, Bánki, Bőthe, Tóth-Király, \& Tropp, 2016), there are benefits to using a combination of these two approaches (Krahé \& Altwasser, 2006). In the present study, we are not interested in investigating knowledge and its role as a mediator, as this is well documented (Pettigrew \& Tropp, 2008; Zagefka et al., 2017; Gordijn, Koomen, \& Stapel, 2001). Instead, our focus is on using the knowledge to develop a way of influencing intergroup attitudes and behaviors that support the effect of direct contact.

\section{Purpose of the Study}

The existing research has focused on reducing intergroup prejudice in schools, and various effective interventions have been identified, including ones based on direct contact (Paluck \& Green, 2009; Ülger, Dette-Hagenmeyer, Reichle, \& Gaertner, 2018). Given the growing need to reduce prejudice against the stigmatized Roma minority, we wished to test the effectiveness of a direct contact based intervention in a Slovak workplace setting.

We hypothesized that the contact based intervention program would 1) improve attitudes among adolescents belonging to the majority population toward Roma people living on the edge of poverty; 2 ) reduce intergroup distance; 3 ) reduce intergroup anxiety; 4) raise intergroup trust; 5 ) improve intergroup approach/avoid tendencies; and 6) increase intergroup intentions to cooperate.

\section{Method}

Following recommendations of the Center for Open Science, we are disclosing all the measures, conditions, data exclusions and so on in the section below. Our data set can be found on the authors' ResearchGate profile.

\section{Participants}

The participants were 150 first and second year students from selective high schools in two midsized towns in the Bratislava region of Slovakia. The sample of 150 children for the pre-intervention analyses consisted of 83 students from School 1 (55.3\%) and 67 students from School 2. The average participant age was 16.1 years $(S D=0.6)$, and ages ranged from 15 to 18 years. We expected to find a medium effect size $(f=$ .25) and using G*Power calculated that 54 was the appropriate total sample size for our mixed design experimental study ( 2 groups, 2 measurements). Therefore, we aimed for at least 27 participants in both groups. This condition was fulfilled, but we ended up with very unequal sample sizes (experimental group $N=39$ and control group $N=111$ ), since we did not want to leave out any peers, who did not participate in the experimental group, but attended the same school. The final dataset of 150 did not include 4 students, who were excluded from the experimental group as they did not attend at least half of the program lessons.

There were no statistically significant differences in the proportion of male students (first school - 38, second school - 29) and female students (first school -45 , second school -38 ) from the two schools $\left(\chi^{2}(1)=.94 ; p=.76 ; \varphi=\right.$ .03). Equally, there were no statistically significant differences between the two schools in terms of participant intergroup attitudes toward the Roma on the edge of poverty (see Table 1), so we merged the datasets for the analysis. 
To ensure the recruitment process was randomized, we asked schools to allocate a code to each of the first and second year students' surnames. In the next step, we randomly selected an equal number of codes (i.e., students) from each class and gave them the opportunity to enroll in the program (i.e., the experimental group). All the students that were approached agreed to this and so were given parental consent forms. No specific measures were applied to prevent selection bias. The remaining students, who were not given the opportunity to enroll in the program were placed in the control group. The pre-intervention analyses were performed on all the first and second year students. There were no statistically significant differences in intergroup attitudes toward the Roma between the control group and the experimental group (see Table 2).

\section{Procedure}

The intervention program consisted of six different sessions (see Table 3).

Two of these, direct contact in a work setting and a knowledge based lecture, were designed to influence intergroup attitudes. At the beginning of the program, the participants in the experimental group were told that the aim of the program was to teach them the basics of project management and about the problems facing a discriminated mi-

Table 1 Comparison of pre-intervention analyses of school 1 and school 2

\begin{tabular}{|c|c|c|c|c|c|c|}
\hline \multirow[t]{2}{*}{ Variables } & \multicolumn{2}{|c|}{$\begin{array}{c}\text { School } 1 \\
n=83\end{array}$} & \multicolumn{2}{|c|}{$\begin{array}{c}\text { School } 2 \\
n=67\end{array}$} & \multirow[t]{2}{*}{$t(148)$} & \multirow[t]{2}{*}{$p$} \\
\hline & $M$ & $S D$ & $M$ & $S D$ & & \\
\hline Intergroup attitudes & 43.1 & 21.6 & 39.9 & 21.2 & .907 & .366 \\
\hline Social distance & 4.6 & 1.8 & 4.6 & 1.8 & .025 & .980 \\
\hline Intergroup anxiety & 3.3 & 1.4 & 2.9 & 1.5 & 1.611 & .109 \\
\hline Intergroup trust & 3.1 & 1.3 & 3.2 & 1.2 & -.791 & .430 \\
\hline $\begin{array}{l}\text { Approach/Avoid } \\
\text { tendencies }\end{array}$ & 4.0 & 1.6 & 3.5 & 1.7 & 1.713 & .089 \\
\hline Cooperation intention & 4.2 & 1.6 & 4.4 & 1.5 & .802 & .424 \\
\hline
\end{tabular}

Table 2 Comparison of control group and experimental group in pre-intervention analyses

\begin{tabular}{|c|c|c|c|c|c|c|}
\hline \multirow[t]{2}{*}{ Variables } & \multicolumn{2}{|c|}{$\begin{array}{c}\text { Control group } \\
\quad n=111\end{array}$} & \multicolumn{2}{|c|}{$\begin{array}{c}\text { Experimental } \\
\text { group } \\
n=39 \\
\end{array}$} & \multirow[t]{2}{*}{$t(148)$} & \multirow[t]{2}{*}{$p$} \\
\hline & $M$ & $S D$ & $M$ & $S D$ & & \\
\hline Intergroup attitudes & 43.0 & 21.5 & 37.7 & 21.0 & 1.324 & .187 \\
\hline Social distance & 4.7 & 1.8 & 4.2 & 1.7 & 1.456 & .147 \\
\hline Intergroup anxiety & 3.1 & 1.5 & 3.2 & 1.2 & -.145 & .897 \\
\hline Intergroup trust & 3.2 & 1.2 & 2.9 & 1.3 & 1.433 & .154 \\
\hline $\begin{array}{l}\text { Approach/Avoid } \\
\text { tendencies }\end{array}$ & 3.7 & 1.6 & 3.5 & 1.6 & 1.129 & .261 \\
\hline Cooperation intention & 4.4 & 1.5 & 3.9 & 1.6 & 1.793 & .075 \\
\hline
\end{tabular}


nority group. The researcher was introduced as an employee of the company running the school program. The participants were told that in order to successfully complete the program they would have to produce a simple plan concerning a fictitious assistance project for the selected minority group and attend at least five of the six lectures.

Two weeks before and after the manipulation, participants completed a social attitudes questionnaire. We marked the questionnaires with unique codes for pre- and post-measurement purposes. They were distributed by the local teachers in the classroom and included a set of questions on social media use and ecological problems in Slovakia. This was done so that the participants would think the questionnaire was a general survey tracking their opinions over time and unrelated to the intervention program. After the second measure had been completed, the participants were thanked and debriefed.

Table 3 Description of procedure and program content

\begin{tabular}{|c|c|c|}
\hline $\begin{array}{c}\text { Session } \\
\text { (presenter) }\end{array}$ & $\begin{array}{l}\text { Length in } \\
\text { hours }\end{array}$ & Content of session \\
\hline \multirow[t]{3}{*}{$\begin{array}{l}\text { 1. Program invitation } \\
\text { meeting (Researcher) }\end{array}$} & .25 & $\begin{array}{l}\text { Meeting with randomly selected students and } \\
\text { introduction to the program. }\end{array}$ \\
\hline & & $\begin{array}{l}\text { Once students had shown an interest in } \\
\text { enrolling, we distributed parental consent forms. }\end{array}$ \\
\hline & & $\begin{array}{l}\text { Students were added to group communication } \\
\text { channel. }\end{array}$ \\
\hline \multirow[t]{2}{*}{$\begin{array}{l}\text { 2. Lecture on project } \\
\text { management basics } \\
\text { (Manager of company } \\
\text { running the program) }\end{array}$} & .75 & $\begin{array}{l}\text { Formal lesson on the basics of project } \\
\text { management: 1) What is project management? } \\
\text { 2) What are examples of common projects? } \\
\text { 3) Why do projects fail? 4) Measuring the success } \\
\text { rate and effectiveness of a project, 5) The life } \\
\text { cycle of a project, 6) How to create your own } \\
\text { project 7) How to collect data, use resources, set } \\
\text { an attainable goal and avoid mistakes in project } \\
\text { management. }\end{array}$ \\
\hline & & $\begin{array}{l}\text { Final student assignment: "based on the } \\
\text { knowledge you have gained, you will be } \\
\text { presenting your own prosocial project on helping } \\
\text { the Roma minority during the final session of the } \\
\text { program" You will receive a certificate for this. } \\
\text { Details of how projects were to be structured } \\
\text { were given in Session } 5 \text {. }\end{array}$ \\
\hline
\end{tabular}

Table 3 continues 
Table 3 continued

\begin{tabular}{lcl}
\multicolumn{1}{c}{$\begin{array}{c}\text { Session } \\
\text { (presenter) }\end{array}$} & $\begin{array}{c}\text { Length in } \\
\text { hours }\end{array}$ & \multicolumn{1}{c}{ Content of session } \\
\hline $\begin{array}{l}\text { 3. } \begin{array}{l}\text { Lecture about creating } \\
\text { prosocial projects (External } \\
\text { expert managing prosocial } \\
\text { projects) }\end{array} \\
\text {.75 }\end{array}$ & $\begin{array}{l}\text { Presentation of a variety of successful prosocial } \\
\text { projects. }\end{array}$ \\
& $\begin{array}{l}\text { Short discussion about the demography of the } \\
\text { Slovak Roma population and a short } \\
\text { brainstorming session on the sorts of problems } \\
\text { students could consider in their prosocial } \\
\text { projects }\end{array}$
\end{tabular}

4. Lecture on "The cost to the State" connected to the "Roma myth" lecture (Economics lecturer)

Knowledge based Intervention (enhancing 6.)

5. Workshop on creating a prosocial project (Researcher)
Lesson on State spending in a variety of domains contrasted with State spending on the Roma minority.

Provision of estimated data on economic wellbeing of Slovak Roma stressing socio-geocultural benefits of raising Roma employment (see Dinga, Ďurana, \& Chovanculiak, 2016)

Students given task of preparing first draft of their prosocial project.

1.5 Students given prosocial project task, including: 1) project goals, 2) expected results,

3) description of project activities, 4) additional information on project (How will the project work? What is the logic behind the project? etc.), 5) budget and timeline, 6) pros and cons of project.

Discussion of students' project drafts from Lecture 4. Assessment of strong and weak points, suggestions for improvement

6

. Educational excursion to a factory with Roma employees and visit to the organization running the school program (Head of the factory with Roma employees/Organization employees)

Direct contact intervention
Visit to factory tied in with lecture on factory project management by head of factory.

Students see work stations and Roma employees at work. Roma employees demonstrate their work duties and give students small gifts.

Following factory trip, students visit the organization running the program. They present their fictitious prosocial projects and receive program attendance certificates and feedback from company employees. 


\section{Measures}

To assess intergroup attitudes, social distance, intergroup anxiety, intergroup trust and approach/avoid tendencies, we adapted the INTERMIN questionnaire, which has been validated for the Slovak population (Lášticová \& Findor, 2016). To ensure the participants would think of the same group members, we redesigned the questions to focus on Roma people living on the edge of poverty.

To assess intergroup attitudes, we asked participants to complete a feeling thermometer to rate, on a scale of 0 to 100 , how positive they felt toward Roma people living on the edge of poverty. To assess social distance, participants were asked to indicate how acceptable they thought situations such as "If a Roma person living on the edge of poverty was your classmate" were, on a 7-point scale ranging from $1=$ not acceptable at all, to $7=$ completely acceptable ( 3 items; Cronbach $\alpha$ $=.94)$. To assess intergroup anxiety, participants were given statements (e.g., "If a new classmate who was a Roma person living on the edge of poverty joined your class") and a set of various possible answers (e.g., "I would feel positive about it") and were then asked to rate the extent to which these answers reflected their feelings, on a 7-point scale ranging from 1 = does not reflect my feelings at all, to $7=$ fully reflects my feelings ( $\mathrm{R}$ ); (4 items, $\alpha$ $=.82$ ). To assess intergroup trust, participants were asked to do the same with statements like "I think Roma people living on the edge of poverty can be trusted", rated on a 7-point scale ranging from 1 = does not reflect $m y$ feelings at all, to 7 = fully reflects my feelings; (3 items, $\alpha=.74$ ). To assess approach/avoid tendencies, participants were asked "How would you react if you had a new classmate in your class who was a Roma person living on the edge of poverty?" with answers such as "I would like to get to know that person", which they had to rate on a 7-point scale ranging from $1=\mid$ strongly disagree, to $7=1$ strongly agree; ( 3 items, $\alpha=.92$ ). To assess cooperation tendency, participants were asked to indicate agreement with two statements: "I would be able to consider cooperating with a Roma person living on the edge of poverty in the future", and "Organizations employing Roma people living on the edge of poverty do not put local inhabitants in danger", rated on a 7-point scale ranging from $1=\mid$ strongly disagree, to $7=$ I strongly agree; ( 2 items, $\alpha$ $=.77)$. All measures showed satisfactory reliability.

To measure intergroup cooperation tendency, we constructed a 2-item scale to accompany the INTERMIN questionnaire. The scale of cooperation intention had satisfactory correlations with all the intergroup factors.

\section{Data Analysis}

We analyzed the data using SPSS and R software, following the standard procedure for descriptive and inferential analyses. We tested the significance of interaction between two factors - time of measurement and group. Both factors had two levels. Pre-intervention and post-intervention measurements were the two time levels, and experimental and control were the two group levels. Based on Levene's test of homogeneity of variances, a robust version of a mixed-design ANOVA had to be applied to intergroup trust and intergroup anxiety, using R package WRS2. This procedure uses trimmed means (trimmed by $20 \%$ by default) to calculate the F-test value, which prevents the results being distorted by outlier observations (Wilcox, 2011). The same procedure was applied to every other intergroup factor as we obtained significant results in the Shapiro-Wilk and Kolmogorov-Smirnov normality tests, and there is currently no 
non-parametric alternative to a mixed design ANOVA (Field, 2018). To test simple main effects within the control and experimental groups separately, paired samples T-test and the robust version of T-test from the WRS2 package were used. The robust version of the paired samples T-test was used for non-normal distributions instead of the Wilcoxon signed rank test, to ensure our methods of statistical analysis were consistent.

\section{Results}

Below we start by describing the differences between the control group and the experimental group for the two pre- and post-intervention time points (see Table 4).

For intergroup attitudes, we found a statistically significant interaction between the levels of the time measures and the groups; the effect was medium $(F(1,92.08)=7.752$, $\left.p=.077, \eta_{p}^{2}=.08\right)$. Students in the experimen- tal group reported more positive attitudes after the intervention than they had before. The difference was statistically significant, and the effect was medium to large $(t(24)=3.16, p=$ $.004, d=.77)$. The post-intervention measure showed no difference between the control group and the experimental group $(t(66)=$ $-0.226, p=.82$ ).

For intergroup trust, we found a statistically significant interaction between the levels of the time measures and the groups; the effect size was small $(F(1,91.95)=4.0697 ; p=0.047$, $\left.\eta_{p}^{2}=.04\right)$. Students in the experimental group reported a higher level of intergroup trust than they had before the intervention. The difference was statistically significant, and the effect was medium $(t(24)=3.16 ; p=.004 ; d=$ .57). The post-intervention measure showed no difference between the control group and the experimental group $(t(66)=-0.51, p=.61)$.

For approach/avoid tendencies, we found a statistically significant interaction between

Table 4 Means and standard deviations of pre-and post-intervention measurements within experimental and control group

\begin{tabular}{lllllll}
\hline \multirow{2}{*}{ Measure } & Group & \multicolumn{2}{c}{ Pre-intervention } & \multicolumn{2}{c}{ Post-intervention } & \\
& & (trimmed) & \multicolumn{1}{c}{ (trimmed) } & (trimmed) & (trimmed) & \\
\hline Intergroup & control & $43.0(44.1)$ & $21.5(20.9)$ & $43.2(44.5)$ & $21.0(19.1)$ & {$[-2.3,3.4]$} \\
attitudes & exp. & $37.7(38.7)$ & $21.0(20.9)$ & $48.2(49.2)$ & $19.8(15.7)$ & {$[3.7,17.5]$} \\
Social & control & $4.7(4.9)$ & $1.8(2.1)$ & $4.4(4.3)$ & $1.6(1.7)$ & {$[-0.8,-0.2]$} \\
distance & exp. & $4.2(4.2)$ & $1.7(2.0)$ & $4.4(4.4)$ & $1.6(1.9)$ & {$[-0.4,0.7]$} \\
Intergroup & control & $3.1(3.0)$ & $1.5(1.9)$ & $3.5(3.4)$ & $1.5(1.5)$ & {$[0.1,0.7]$} \\
anxiety & exp. & 3.2 & 1.2 & 3.2 & 1.3 & {$[-0.5,0.4]$} \\
Intergroup & control & $3.2(3.2)$ & $1.2(1.4)$ & $3.3(3.3)$ & $1.2(1.4)$ & {$[-0.2,0.3]$} \\
trust & exp. & $2.9(2.9)$ & $1.3(1.6)$ & $3.6(3.6)$ & $1.6(1.9)$ & {$[0.1,1.3]$} \\
Approach / & control & $3.9(3.9)$ & $1.6(1.8)$ & $3.8(3.8)$ & $1.6(1.5)$ & {$[-0.3,0.2]$} \\
Avoid tend. & exp. & 3.5 & 1.6 & 4.4 & 1.7 & {$[1.4,3.6]$} \\
Cooperation & control & $4.4(4.4)$ & $1.5(1.7)$ & $4.3(4.3)$ & $1.5(1.8)$ & {$[-0.4,0.2]$} \\
intention & exp. & $3.9(3.9)$ & $1.5(1.8)$ & $4.7(4.7)$ & $1.7(2.5)$ & {$[0.2,1.5]$} \\
\hline
\end{tabular}

Note. trimmed values are not stated if a standard parametric paired-samples T-test was used to test the differences between pre- and post-intervention measurement 
the levels of the time measures and the groups; the effect size was medium $(F(1,87.14)=9.15$; $\left.p=.003, \eta_{p}^{2}=.095\right)$. Students in the experimental group reported more positive approach/ avoid tendencies than they had before the intervention. The difference was statistically significant, and the effect size was medium to large $(t(38)=3.45 ; p=.001 ; d=.78)$. No statistically significant change in approach/avoid tendencies was found in the control group $(t(66)=0.48, p=.64)$

For cooperation intention, we found a statistically significant interaction between the levels of the time measures and the groups; the effect size was medium $(F(1,88.67)=$ 7.16; $\left.p=.009, \eta_{p}^{2}=.075\right)$. Students in the experimental group reported a higher cooperation intention than they had before the intervention. The difference was statistically significant and the effect was small $(t(24)=$ 2.55; $p=.02 ; d=.38$ ). The difference between the two measures in the control group was not significant $(t(66)=.83, p=.41)$.

For social distance, we found a statistically significant interaction between the levels of the time measures and the groups; the effect size was small $\left(F(1,108.65)=5.19 ; p=.025, \eta_{p}^{2}\right.$ $=.046)$. Students in the experimental group reported a smaller social distance after the intervention than they had before the intervention, but the difference was not statistically significant $(t(24)=.67, p=.51)$. However, in the control group social distance was reduced and statistically significant, and the effect size was small $(t(66)=3.289, p=.002, d=0.26)$

For intergroup anxiety, we found a statistically non-significant interaction between the levels of the time measures and the groups; the effect was small $(F(1,102.06)=1.59 ; p=$ $.21)$. Students in the experimental group reported approximately the same attitudes after the intervention as they had before the intervention $(t(38)=.203, p=.84)$. In the control group, intergroup anxiety increased significantly with a small effect $(t(66)=2.834$, $p=.01, d=0.24$ )

The results support the hypothesis that the intervention program has a positive influence on intergroup attitudes, trust, approach/ avoid tendencies and cooperation intention. Intergroup anxiety was not affected by the intervention and social distance remained unchanged in the experimental group, but decreased in the control group.

\section{Discussion}

The present applied study sought to assess the effectiveness of a direct contact intervention in a work setting that was part of a complex intervention program tackling intergroup prejudice against the Roma minority among Slovak adolescents. Taken together, the results of the present study indicate that this is the first positive attempt to reduce Roma prejudice in Slovakia, a country with a high level of prejudice (European Commission, 2015), using an intervention which includes direct contact in a work setting. More specifically, we found that participants in the experimental group who attended the Junior Project Manager program, which included direct contact experience in a work setting and an anti-prejudice lecture, reported more positive intergroup attitudes, greater intergroup trust, more positive intergroup approach/avoid tendencies and a more positive tendency for cooperation intention.

To a large extent, our findings on direct contact are in line with Allport's (1954) intergroup concept and the findings of Pettigrew and Tropp $(2006,2008)$ and Kende, Tropp, and Lantos (2017). The findings are also in line with those of Krahé and Altwasser (2006), which show that complex cognitive and behavioral interventions can be effective in reducing prejudice. Data collected on the intergroup factors of social distance and intergroup anxiety did 
not support the hypothesis that the intervention program would have a positive influence. Binder et al. (2009) point out that when contact with outgroup members is perceived as typical then contact effects become stronger, especially on social distance and negative emotions. On the other hand, in cases where there is typically less contact with outgroup members - such as between members of the Slovak majority population and the Roma - the influence may be insignificant. One reason why intergroup anxiety was not reduced could be that the anxiety consists of three interrelated components - affective, cognitive and physiological - (Stephan, 2014) and that our short-term prevention program was extensive enough to address the cognitive component, but not to reduce intergroup anxiety.

The present study has several important theoretical and practical implications. Previous research has produced some unrepresentative results showing that greater acceptance of Roma is generally associated with higher levels of direct experience (see Drál' \& Findor, 2016). In some cases, greater contact with Roma may even correspond with stronger anti-Roma attitudes among the non-Roma (Kende, Tropp, \& Lantos, 2017). Our empirical research shows that in Slovakia, where prejudice is often explicit among adult respondents (Kövérová, 2016), the Junior Project Manager program has the potential to reduce intergroup prejudice among adolescents.

The recent skepticism regarding direct contact (Paluck, Green, \& Green, 2018) has been raised in relation to the canonical meta-analysis of contact hypothesis published in 2006 by Pettigrew and Tropp. Objections relate to the effect of contact on prejudice based on 515 contact studies, which varied widely in terms of research design. Just $5 \%$ of the studies in the database employed an experimental design. As our study included a field experiment design, it contributes further to the research on direct contact hypothesis effects in a natural non-laboratory factory setting. As school trips are part of the Slovak curriculum, conducting contact research in a factory setting is important as is researching other possible contact settings. Due to field experiment design, we also could not prevent students, who participated but did not participate in the intervention, to talk to each other after sessions, which may have influenced the results.

The experiment has limitations that could be addressed in future research. First, previous studies have shown that intensity of intergroup contact with the Roma minority may have a moderating effect on prejudice (Gallová-Kriglerová, 2006). For example, teachers living in regions with a higher concentration of segregated Roma settlements had more negative attitudes compared to those living with lower concentration, and there was no correlation with age or years of teaching practice (Rosinský, 2009). As all our participants were from the Bratislava region, which has a lower number of Roma settlements than some other regions (Mušinka et al., 2014), our results cannot be generalized to all Slovak adolescents. Ideally, future research would involve participants from various regions.

Another methodological issue we faced was the large difference between the sample sizes of the control group and the experimental group. The unequal sample size led to more observations for some combinations of factor levels, making it more difficult to distinguish the effects of the separate factors (Shaw \& Mitchell-Olds, 1993). It also reduces the robustness of the parametric ANOVA (Field, 2018). However, we dealt with this issue by using a robust version of a mixed design ANOVA that is appropriate where assumptions of normality and homoscedasticity are not met (Wilcox, 2013).

Social desirability, "the tendency to give answers that make the respondent look good" 
(Paulhus, 1991, p. 17), is another limitation of our study that could have skewed the results. We tried to achieve that participants will not connect filling questionnaires with the intervention program by applying these precautions: there were 1) various other measures not related to intergroup relations in the questionnaires; 2) questionnaires distributed by individuals who were not part of the program; 3) questionnaires distributed over a relatively long period of time between preand post-intervention. Nonetheless the intergroup behavioral measurements may elicit social desirability in respondents, prompting them to answer in the way they feel is expected. We suggest that a variety of techniques be used together to mitigate against social desirability and achieve better validity control (Durmaz, Dursun, \& Kabadayi, 2020), still, no one method for coping with social desirability bias can provide success completely (Nederhof, 1985).

According to the ingroup identity model (Gaertner, Rust, Bachman, Anastasio, \& Dovidio, 1994), when the setting in which the direct contact takes place reinforces a feeling of shared identity among participants, social distance tends to diminish. Looking back at this sixth session, greater emphasis on Allport's condition of group cooperation could have enhanced the effect of the intervention (Allport, 1954; Pettigrew \& Tropp, 2006). The participants met members of the Roma minority in their work setting but did not work alongside them. It is possible that negative aspects like anxiety may have negatively impacted the sense of shared ingroup identity. As in other studies assessing the role of shared ingroup identity (Gómez, Dovidio, Gaertner, Fernández, \& Vázquez, 2013; Riek, Mania, Gaertner, McDonald, \& Lamoreaux, 2010), we suggest this mediator should be investigated in future research, as should the moderating role of the perceived quality of the program and the contact itself.

\section{Conclusion}

The present study is further evidence of the efficacy of direct contact based interventions. It has also produced the first results indicating that direct contact in a work setting is effective in a Slovak context, where prejudices toward Roma are high. The research based on the Junior Program Manager intervention revealed significant positive effects on several behavioral tendencies: positive intergroup attitudes, intergroup trust, approach/avoid tendencies and cooperation intention.

Given recent European surveys on Roma prejudice, it seems likely that there will be a continued, and probably even more pressing, need to understand the complex forces that shape social stereotyping and intergroup relations. Also further research is needed to better understand the processes, vulnerabilities and resiliencies that mediate stereotypes and prejudice especially regarding ethnicity.

\section{Acknowledgements}

Project was supported by GRANT MLADYCH no. UK/410/2018 by Comenius University and by the Slovak Research and Development Agency under contract no. APVV-14-0531. Special thanks to dr. Katerina Lukavská (consultations provided by Visegrad Fund Scholarhip Scholarship 51810848), Branislav Uhrecký, Lenka Valuš, Terrence Mudder and Sharon Mudder for useful comments.

\section{Authors' ORCID}

Juraj Petrík

https://orcid.org/0000-0001-5162-1577

Miroslav Popper

https://orcid.org/0000-0002-9767-2238 


\section{References}

Allport, G. W. (1954). The Nature of Prejudice. Cambridge: MA: Addison-Wesley. https://doi. org/10.1525/aa.1955.57.2.02a00610

Beelmann, A., \& Heinemann, K. S. (2014). Preventing prejudice and improving intergroup attitudes: A meta-analysis of child and adolescent training programs. Journal of Applied Developmental Psychology, 35, 10-24. https://doi. org/10.1016/i.appdev.2013.11.002

Bigler, R. S., \& Liben, L. S. (2006). A developmental intergroup theory of social stereotypes and prejudice. Advances in Child Development and Behavior, 34, 39-89. https://doi.org/10.1016/ s0065-2407(06)80004-2

Dinga, J., Ďurana, R., \& Chovanculiak, R. (2016). Rómovia a sociálne dávky: Sú Rómovia problémom verejných financií Slovenska? [Roma people and welfare benefits: Are Roma people a public finance problem in Slovakia?]. Bratislava, Slovakia: INESS. Retrieved July 17, 2019, from http://iness.sk/mytus/wp-content/uploads/ ROMA-2016.pdf

Drál', P., \& Findor, A. (2016). Teachers as researchers? Assessing the impact of pedagogical interventions on pupils' attitudes. Human Affairs, 26, 271-287. https://doi.org/10.1515/humaff-2016-0024

Durmaz, A., Dursun, I.., \& Kabadayi, E. T. (2020). Mitigating the effects of social desirability bias in self-report surveys: Classical and new techniques. Applied Social Science Approaches to Mixed Methods Research (pp. 146-185). https:// doi.org/10.4018/978-1-7998-1025-4.ch007

Eurobarometer (2015). Discrimination in the EU in 2015. Retrieved July 17, 2019, from https:// ec.europa.eu/commfrontoffice/publicopinion/ index.cfm/ResultDoc/download/DocumentKy/68005

Field, A. (2018). Discovering statistics using IBM SPSS statistics. London: SAGE publications.

Gaertner, S. L., Rust, M. C., Bachman, B. A., Anastasio, P. A., \& Dovidio, J. F. (1994). The contact hypothesis: The role of a common ingroup identity on reducing intergroup bias. Small Group Research, 25, 224-249. https://doi. org/10.4135/9781483327648.n10
Gallová-Kriglerová, E. (2006). Prieskum názorov mladých l'udípre potreby kampane All Different - All Equal. [Opinion poll of young people for the All Different-All Equal campaign]. Bratislava: luventa. Retrieved July 17, 2019, from https://www.iuventa.sk/files/documents/ 7 vyskummladeze/spravy/davm010/vyskum kivr.pdf

Gómez, Á., Dovidio, J. F., Gaertner, S. L., Fernández, S., \& Vázquez, A. (2013). Responses to endorsement of commonality by ingroup and outgroup members: The roles of group representation and threat. Personality and Social Psychology Bulletin, 39, 419-431. https://doi. org/10.1177/0146167213475366

Gordijn, E. H., Koomen, W., \& Stapel, D. A. (2001). Level of prejudice in relation to knowledge of cultural stereotypes. Journal of Experimental Social Psychology, 37, 150-157. https://doi.org/10.1006/ jesp.2000.1443

Kende, A., Tropp, L., \& Lantos, N. A. (2017). Testing a contact intervention based on intergroup friendship between Roma and non-Roma Hungarians: Reducing bias through institutional support in a non-supportive societal context. Journal of Applied Social Psychology, 47, 47-55. https://doi.org/10.1111/jasp.12422

Kövérová, E. (2016). Školy ako pozitívne deviantné systémy [Schools as positively deviant systems]. Pedagogika.sk, 7, 77-102.

Krahé, B., \& Altwasser, C. (2006). Changing negative attitudes towards persons with physical disabilities: An experimental intervention. Journal of Community and Applied Social Psychology, 16, 59-69. https://doi.org/10.1002/casp.849

Lajčáková, J., Gallová-Kriglerová, E., Kadlečíková, J., Balážová, Z., \& Chudžíková, A. (2017). Riešenie nezamestnanosti Rómov: Od mýtu k praxi a spät' [Solving Roma unemployment: From myth to practice and back]. Bratislava, Slovakia: RAVS. Retrieved July 17, 2019, from http://cvek.sk/?attachment id=2227\&download=true

Lášticová, B., \& Andraščiková, S. (2016). Sociálne reprezentácie Rómov a utečencov: Analýza vol'ných asociácií. [Social representations of Roma and refugees: Analyses of free associations] In J. Kanovská Halamová (Ed.), Komunitná psychológia na Slovensku (pp. 53-59). Bratislava: FSEV-UK. ISBN 978-80223-4204-9 
Lášticová, B., \& Findor, A. (2016). Developing explicit measures of stereotypes and anti-Roma prejudice in Slovakia: Conceptual and methodological challenges. Human Affairs, 26, 233-252. https://doi.org/10.1515/humaff-2016-0022

Lee, Y., Muennig, P., Kawachi, I., \& Hatzenbuehler, M. L. (2015). Effects of racial prejudice on the health of communities: A multilevel survival analysis. American Journal of Public Health, 105, 2349-2355. https://doi.org/10.2105/ajph.2015.302776

Marcinčin, A., \& Marcinčinová, L'. (2014). Trh práce a Rómovia: Stav, príciny a odporúčania [Labor market and Roma people: Current state, causes and recommendations]. Bratislava, Slovak Republic: Prognostický ústav Slovenskej akadémie vied. Retrieved July 17, 2019, from http://prog. sav.sk/sites/default/files/2018-03/Uprav Marcincin clanok3 PP2 2014.pdf

Minkenberg, M. (2017). The rise of the radical right in Eastern Europe: Between mainstreaming and radicalization. Georgetown Journal of International Affairs, 27-35. https://doi.org/10.1353/ gia. 2017.0005

Mušinka, A., \& Pollák, M. (2014). Vybrané problémy začleňovania Rómov na trh práce [Selected issues in Roma integration on labor market]. In V. Páleník, T. Želinský, \& L. Fašungová (Ed.). Politika zamestnanosti budúcnost' pre Slovensko (pp. 108-128), Inštitút zamestnanosti. Retrieved July 17, 2019, https://www.iz.sk/download-files/sk/ publikacia-politika-zamestnanosti.pdf

Mušinka, A., Škobla, D., Hurrle, J., Matlovičová, K., \& Kling, J. (2014). ATLAS rómskych komunít na Slovensku 2013 [Atlas of Roma communities in Slovakia 2013]. Bratislava: UNDP.

Nederhof, A. J. (1985). Methods of coping with social desirability bias: A review. European Journal of Social Psychology, 15, 263-280. https://doi. org/10.1002/ejsp.2420150303

Orosz, G., Bánki, E., Bőthe, B., Tóth-Király, I., \& Tropp, L. R. (2016). Don't judge a living book by its cover: Effectiveness of the living library intervention in reducing prejudice toward Roma and LGBT people. Journal of Applied Social Psychology, 46, 510-517. https://doi.org/10.1111/ jasp.12379

Oskamp, S. (2000). Reducing prejudice and discrimination. Mahawah, NJ: Erlbaum. https://doi. org/10.4324/9781410605634
Paluck, E. L., \& Green, D. P. (2009). Prejudice reduction: What works? A review and assessment of research and practice. Annual Review of Psychology, 60, 339-367. https://doi.org/10.1146/ annurev.psych.60.110707.163607

Paluck, E. L., Green, S., \& Green, D. P. (2018). The Contact Hypothesis Reevaluated. Behavioral Public Policy, 1-30. https://doi.org/10.1017/bpp.2018.25

Pascoe, E. A., \& Smart Richman, L. (2009). Perceived discrimination and health: A meta-analytic review. Psychological Bulletin, 135, 531-554. https://doi.org/10.1037/a0016059

Paulhus, D. L. (1991). Measurement and control of response bias. In J. P. Robinson, P. R. Shaver, \& L. S. Wrightsman (Eds.), Measures of personality and social psychological attitudes (pp. 17-59). San Diego: Academic Press. https://doi. org/10.1016/b978-0-12-590241-0.50006-x

Pettigrew, T. F., \& Tropp, L. R. (2006). A meta-analytic test of intergroup contact theory. Journal of Personality and Social Psychology, 90, 751-783. https://doi.org/10.1037/0022-3514.90.5.751

Pettigrew, T. F., \& Tropp, L. R. (2008). How does intergroup contact reduce prejudice? Meta-analytic tests of three mediators. Electronic Journal of E-Learning, 10, 107-119. https://doi. org/10.1002/ejsp.504

Popper, M., Szeghy, P., \& Sarkózy, S. (2009). Rómska populácia a zdravie: Analýza situácie na Slovensku [Roma population and health: Analyses of the situation in Slovakia]. Bratislava, SK: Partners for Democratic Change Slovakia. Retrieved July 17, 2019, http://www.gitanos.org/ upload/13/60/Eslovaquia-corrected.pdf

Riek, B. M., Mania, E. W., Gaertner, S. L., McDonald, S. A., \& Lamoreaux, M. J. (2010). Does a common ingroup identity reduce intergroup threat? Group Processes and Intergroup Relations, 13, 403-423. https://doi.org/10.1177/1368430209346701

Rosinský, R. (2009). Etnické postoje učitel'ov, študentov a žiakov I. stupňa ZŠ (s akcentom na rómsku etnickú skupinu) [Ethnic attitudes of teachers, students and stage one primary school pupils (focusing on the Roma ethnic group)]. Nitra, SK: FSVaZ-UKF.

Shaw, R. G., \& Mitchell-Olds, T. (1993). Anova for unbalanced data: An overview. Ecology, 74, 1638-1645. doi: 10.2307/1939922. https://doi. org/10.2307/1939922 
Stephan, W. G. (2014). Intergroup anxiety: Theory, research, and practise. Personality and Social Psychology Review, 18(3), 239-255.

Tomková, J. (2016). Postoje slovenských adolescentov $\mathrm{k}$ menšinám: Film RYTMUS sídliskový sen ako nástroj prevencie. [Attitudes of Slovak adolescens toward minorities: Movie RYTMUS as a tool of prevention]. Retrieved February 2, 2020, http://sidliskovysen.sk/documents/Postoje-slovenskych-adolescentov-k-mensinam-Sprava-z-vyskumu-2016.pdf

Ülger, Z., Dette-Hagenmeyer, D. E., Reichle, B., \& Gaertner, S. L. (2018). Improving outgroup attitudes in schools: A meta-analytic review. Journal of School Psychology, 67, 88-103. https://doi.org/10.1016/i.jsp.2017.10.002

Vašečka, M. (2011). Vzájomné vztáahy Rómov a ne-Rómov na pozadí kultúry ne-inkluzívnosti
[Roma and non-Roma relations in a noninclusive culture]. Presented at "Event on Structural Funds contribution to Roma integration in Slovakia". Retrieved July 17, 2019, http://ec.europa.eu/regional policy/archive/conferences/ roma2011/doc/conclusions/25052011 vasecka.ppt

Wilcox, R. (2011). Introduction to robust estimation and hypothesis testing. Amsterdam: Academic Press. https://doi.org/10.1016/c2010-0-670441

Zagefka, H., González, R., Brown, R., Lay, S., Manzi, J., \& Didier, N. (2017). To know you is to love you: Effects of intergroup contact and knowledge on intergroup anxiety and prejudice among indigenous Chileans. International Journal of Psychology, 52, 308-315. https://doi.org/10.1002/ ijop.12229 